\title{
Musicians and Nation Building- Need for Quality Control: Old and New Generation Music and Musicians Exemplified
}

\author{
Eunice U. Ibekwe \\ *http://dx.doi.org///0.43 I4/ujah.v17i3.8
}

\section{Abstract}

The growth of any nation is largely dependent upon a number of factors, which may be viewed from such perspectives as, fiscal status, economic development, political system, cultural awareness, social integration, security management, educational attainment, health facilities and other global endowment and or empowerment. One may then ask, what business has Music and Musicians on these afore mentioned developmental strategies. Obviously, music and musicians are integral to the full realization of any nation's growth. They are culture propagators, indicators or pointers to nation's identity, revenue generators, social and health promoters, moral censors, astute educationists and in fact, they constitute strong steering forces to a whole gamut of nation building. Therefore, if such powers are credibly inherent in music and musicians, the quality should be of utmost importance, otherwise the situation becomes farcical and unyielding to nation building. Well cultured individuals will make a better society. Standing on such premise, the paper made a comparative case, by critically analyzing some samples of music drawn from old and modern artistes between $60^{\text {ss }}-80^{\prime s}$, and 2000 to date. It was discovered that most of the old generation music and musicians fulfill societal expectations better than the new and suggest that the later be properly censored to achieve a desired objective. 


\section{Introduction}

The superfluity or the alarming influx of music and musicians in today's entertainment industry has become a worrisome experience that one begins to wonder in utmost bewilderment the nature and quality of music that infiltrate the society as well as the artistes that produce them. This discourse will tilt majorly towards popular music business. The purpose of music making in African sense of value does not mean filling the air with synthetic buzzing hits nor the consequent cacophony of uncontrolled sonic presentations, rather and more importantly music should ideally aim at satisfying the societal needs and expectations of it. Unfortunately, the quest for materialism is now compromised at the expense of quality productions. Ingénue motives have taken a serious toll on the type of music in circulation in such a way that if nothing is done to minimize it; our entertainment industry which is flooded with poor quality musical productions in the name of trendy hits will eventually collapse.

The situation as it is now demands both governments' and corporate body's censorship, but unfortunately, the duo seems to be too quiet about the raging situation. The trend has become too devastating that instead of the artistes or the musicians performing their designated duties which are embroiled in the power of their music to entertain, educate, socialize, symbolize, mobilize, motivate, sanitize, soothe, heal, exorcize, criticize, and acculturate, they among other things concentrate pornographic displays. And instead of setting the pace and controlling the audience' taste of music, the later now manipulate and redirect the artiste's creative ingenuity. This happens mostly among the youths who now dictate the type of music they would want to listen to and those that 
would receive their patronage not minding whose ox is gored or the harm their action will cause in society.

Worst still, the availability of computer based gadgets, small or one room recording studios and dearth of live performances have aggravated the entire situation; hence it has facilitated the production of low quality music and musicians. Agreeably, a good number of our youths now claim or parade themselves as musicians of various categories operating at different levels of musicality, either as a gospel singer, reggae exponent and other types of popular music performances. The irony of it all is that most of the time, the products packaged for the eager waiting audience has little or no messages at all, not to talk of contributing to nation building through the message of their music. It should be noted that music in African culture has quite a different conception in both function and purpose and should not be perceived from western perspectives or be compared with what obtains in the Western world.

Ibekwe (2010) asserts that "Africans attach great values to cultural demeanors such as expressive power of song texts, symbolic and aesthetic disposition of costumes and endearing messages of body movements" (36) therefore any music that lacks such expressive qualities is normally less appreciated. In addition, lbekwe, (2013) avers that " the amount of recognition a musician receives in any (African) society depends on the effectiveness of his music in conveying the required message(s) which is based on the communities' understanding of the concept". (163) Emphatically, Nzewi in Ibekwe, (2013) infers that, " the misunderstanding of ...(the) nature and logic (of African music) has given rise to a lot of misinformed and speculative theories about African's musical intellection" (163). Having that in mind, an artiste is therefore expected to operate within his existing socio- 
cultural milieu to avoid being misinterpreted. All these assertions make the idea of censorship and quality control of musical products very imperative if they must yield positive result.

\section{Old Music and Musicians exemplified}

When we talk of old music and musicians, we use time frame as point of reference. In this paper old music and musicians refer to those music and musicians that operate between 1960's and 1990's. Within this period in question, musicians produce musical works that are meaningful, thoughtprovoking, entertaining, educative and generally accepted by people. Although they are not exposed to or even underwent any prescribed screening or censorship yet, they are obviously guided naturally by what may be regarded as societal philosophical concept. Nzewi, (2007) stresses that, "Africa conceptualizes music in two primary and interconnected perspectives". (I I5) According to him,

A musical arts production and presentation that is accredited in the public space must have the qualification of :

- Making musical sense, which is an intellectual activity concerned with the conformations of sound, phonic resources, and artistic wholeness in musical arts theatre

- Making musical meaning, which mandates creative logic and grammar to accomplish philosophical and psychological intentions as well as strategize human-making structures and presentational dynamics. (I I5)

In other words, music is appreciated when it is sensible and meaningful as well as conforms to the cultural stipulations of a people; otherwise it becomes unproductive to nation's growth. Some of the musicians of this period include 
-Celesting Ukwu

-Gentle man Mike Ejeagha

- Victor Uwaifo

- Fela Anikulapo Kuti

- Chief Stephen Osita Osadebe

- Oliver de Coque

- Onyeka Onwenu

- Sunny Ade

- Ebenezar Obey

- Sonny Okosun

- Muddy lbe -Haruna Ishola and so on

These are just few examples of musicians whose music are believed to operate within the philosophical rationalization of African man, and which seem to adhere to the cultural expectations and aesthetic appreciation of the target audience. For instance, when Okafor, Nwokike, Eziechi, and Egudu (1999:7) were describing the lyrics of Celestine Ukwu's songs, they aver, "for Celestine Ukwu, most of his songs are philosophical, and such themes as providence, death, life, social relationships and retribution are persistent features. A few of them are on love, praise and nationalism". It can also be said that musicians are often prophetic when enmeshed in a state of spiritual manipulation. A look at some musical examples from some of these musicians will make an inroad into what the paper is claiming to argue or propagate.

\section{Celestine Ukwu and his music}

Celestine Ukwu was a music prodigy, born in Umuavulu Abo in Udi L.G.A of Enugu State. Being a progeny of autochthonous musicians, he got his formal music exposures through his uncle who was a school teacher. The most striking fact about Celestine's music is the philosophical 
import of his song texts displayed in the use of idioms and proverbs. Little wonder then he was nick-named -Celestine Ukwu -'the philosopher'. His musical talents which owe much to his genealogical background saw him as a renowned minstrel as well as a popular musician. Okafor et al (1999:2) postulates, "having come from a musical family, Celestine inherited the art of minstrelsy from his father very early in life'. Most of Celestine's songs are outstandingly message driven for humanities, and that accorded him many fans during his life time and after. A look at some of his songs thus

Ejina uwa anya isi- do not boast of what you have Onye ejina uwa wee mee onu

Let none boast because of his wealth

Onye e tinyena obi ya n'echi

Let none put his faith in tomorrow

Onye a tinyena obi n'odiniru

Let none put his heart into the future

Maka na odiniru ebuka

For future is too great

Echi di ime

Tomorrow is pregnant

Anyi a maro ife o ga amu

We do not know what it will beget

Ife e mene onye ozo nu

Whatever happens to another person

Umu ibe onye a mukwania amu o

Kinsfolk, do not deride him

O nwero onye ma ka nke ya ga esi dinu

(For) nobody knows how his own will be

Ife anyi no bu onye melu ike ya nu, o naa

Our lot is to do our utmost and die 
Ndi be anyi o na abu ufodu kpatasia aku nk'uwa

My people, when some acquire wealth

Fa eloo no ebe a k'ife ncha jedebelu

They think it is the end of the world

Anyi a di elotazi na enu-uwa nke a anyi no a buro be anyi

We forget that this world is not our home

0 nwerokwanu onye na-abu o nwuru a kwalu ngwongwo nine 0 nwelu kwanyelu ya n'ini

Nobody dies and is buried with all his wealth

Ife ndia nine di anyi bia

All these things were there before our birth

Fa ncha ga adikwa anyi a naa

They will remain after our death

Nyabu onye ejina nke o nwelu nya isi

Therefore, let none boast because of his possessions

Onye ejina nke o nwelu wee mee onu

Let none boast because of his wealth

( In Okafor et al 1999)

This excerpt condemns boasting in every sense of it. Most often people boast of wealth, affluence, position, power, beauty and so on. Celestine warns that those things are not permanent and therefore people should restrain from boasting unnecessarily. This is a bitter truth of life and one should not lose sight of such existential realities in ones' life's endeavour. In another song, Ima echi -Do you know tomorrow, the message is two dimensional. Celestine tries to give hope to the hopeless as well as reminding the well-to-do that no condition is permanent. As he questions 'I mago nke echi ga amu?-do you know what tomorrow will bring? It may bring good or it may bring bad, no one knows which. The world is full of uncertainty therefore people should desist from acting with impunity and extremity thinking that nothing will happen. These are some of Celestine's messages which if 
imbibed will make a better human beings with better purpose and prospects.

\section{Gentleman Mike Ejeagha and his music}

Gentleman Mike Ejegha as fondly called is a native of Imezi Owa in Ezeagu Local Government Area of Enugu State. Most of his songs are presented in what is popularly called 'akuko na egwu' literary -story in music. He is very much at home with the Language and philosophy of lgbo culture which may be traced back to his early background, and that, he always portrays in his music. According to Okwu (2014:12)

Ejeagha is well cultivated into the sage wisdom associated with local dwellers under the tutelage of grandfathers or mothers. This clearly manifests in his folklores, proverbs and philosophical wisdom of the sages of the old age...His music is condensed in meaning, existential realities, moral stories with heavy moral lesson especially proper for child training, character,, moral formation and stabilization of the community

The above submission is truism about the functions of music and musicians. Ejeagha is not only philosophical but always abreast with environmental or societal happenings of the moment. All these are captured in the text of his music, thus

Agbata obi onye bu nwanne ya- One's neighbour is his kin, Ndi be anyi na-atu n'inu na-asi, na agbata obi onye ka nwanne bi n'agu

Our people has a saying that one's neighbour is better than his kin in a distance 
Ya bu n'iga amalu na agbata obi gi na ya bi n'uno, mobu n'ilo kakwanu nwanne bi n'agu

So you have to know that your close-door neighbour is more to value than your kin in a distance

Gi na agbata obi gi esekwana okwu. Gi na ya ebune iwe n'obi Do not fall in dispute with your neighbour. Do not go at loggerhead with your neighbor

Obulugodu na gi na ya esegodu okwu, dozienu ya bu okwu Even if you quarrel with your neighbour, settle the dispute

Makana onwero onye ma onye ga enyelu ibe ya aka echi nile For no one knows who will be of assistance to the other tomorrow

Makana ndi be anyi na-atu n'inu si, na agbata obi onye bu nwanne ya

For our people have a saying that some one's neighbor is his kin

Agbata obi kakwazi nwanne bi n'agu

Your neighbor is better than your kin in a distance (Chorus) Mammae, mammae...

Agbata obi onye bu nwanne ya

Some one's neighbor is his kin

Obulu na nwanne gi anoro nso, kpokuo agbata obi k'onyelu gi aka If your kin is not around, call upon your neighbor to assist you

Obulu na mmili na-agu gio, ma nwanne gi anoro nso, jekene be agbata obi jee kulu mmili nuo... 
If you are thirsty and your kin is not around, go to your neighbor and fetch water to drink...

And so on (excerpts from Okwu, 20l4)

This is a message of peace and love to society. It cautions that there should be a harmonious co-existence among neighbours. This is very necessary because, a close-door neighbor can render help that demands urgent attention more readily before a brother who lives a far off. But if there is quarreling, bickering, backbiting, scheming and so on such assistance would not be rendered, and that might endanger the situation. In some cases a good neighbour can even do more than a brother where there is peace and unity.

Also where there is harmonious co-existence, developmental projects are made possible. There are other message- driven songs of Mike Ejeagha such as, Onye ndidi, -the patient- an adage says that' the patient dog eats the fattest bone'. It is an admonition for people to do things with caution, moderation and not to be too desperate over things to the extent of being too unreasonable. The rate at which people pursue money and other material things at the expense of love, respect for elders and tradition is quite unbecoming. The song advises that people should be patient and take things easy. Odogwu na ali enu is another thought provoking episode. The world is full of ups and downs. A rich man today may become a poor man tomorrow. No condition is permanent. The song teaches that no matter how bad a situation might be, it is not the end of the road, and it does not worth taking ones' life. This story in music is about a rich man who incidentally became poor as a result of circumstances beyond his powers (fire disaster that claimed almost everything he had). Out of desperation or hopelessness, he decided to eliminate his life by hanging 
himself in an evil forest. In the process, another man who was cast into the evil forest as a result of some health challenges (a lame from birth) who still wanted to live amidst all odds warned him never to fall on him. At that moment the rich man realized his foolishness and went home reassured, with a resolve that if a helpless lame is still having hope of living it would be a stupid act for him to lose his life for mere material things.

Further still, the song -Onye nwee o na- ebe onye enwero o n'e ebe - 'he who has complains, and he who has not also complains'- condemns the insatiable and avaricious nature of man. The lesson is that one should learn to be content with what one has. If people are contented with what they have, there won't be avarice, looting of government treasury, theft and embezzlements.

\section{Oliver De Coque and his music}

Oliver De Coque is a native of Ezinifite, in Nnewi South Local Government Area of Anambra State. His real and full name is Oliver Sunday Akanite. His musical journey started from what is called egwu ekpili before he graduated into a full blown high life exponent in the early seventies. His music is message driven, thought provoking, challenging, encouraging and advisory. He captures every raging event or every prevalent situation for his music. Any music rendered is a lesson package for the masses. For instance, his message on gender discrimination in Igbo society is a thought provoking message for those who see the training of female child in school as a futile effort since according to them; women are meant to be given out in marriage, a treasure that would eventually go to another person. Nwa bu nwa-child is child (whether male or female) as the song goes cautions that male and female children should be given equal opportunity in their 
training, precisely education, because as he said a well trained female child is as beneficial and productive as the male in the family. The advice goes thus

Ndumodu $m$ na-enye onye obuna n'enu uwa, bu onye muta nwa, ya zua ya n' akwukwo. Akwukwo di mkpa n'enu uwa ma nwoke ma nwanyi, Akwukwo di mkpa n'enu uwa ma nwoke ma nwanyi ooo! onye obuna muta nwa ya zua ya akwukwo, oburu godi nwa ogbenye zua ya ka nwa gi ooo! onye zulu nwa ogbenye chukwu ga-agozi ya n'enu uwa ooo!

Nwoke malu akwukwo n'enu uwa ofu uzo ka ibe ya ooo!. Nwanyi malu akwukwo n'enu uwa ofu uzo ka ibe ya ooo!. Ife o masiri ya o jee ruwazie a, o na-azu afia o na-aru oru onyibo, ife o masiri ya o jee mewazia -a. Nwanyi gua akwukwo ofu uzo ka ibe ya. Nwa bu nwa a. Amulu nwoke amulu nwanyi nwa bu nwa. Onye ma isi ga-echi eze.

Nwanyi gua akwukwo n'enu uwa ofu uzo ka ibe ya n'enu uwa.

O bughi doctor, o buru engineer, o bughi lawyer, o buru chief Judge, nwanyi buru Minister o na-eme ofuma, o buru president, o na-eme ofuma, nwanyi ruba oru onyibo, o naeme ofuma, o zuba afia, o di ka o bu ya kasimma, osibe nri o dika o bu ya kasima, o na-akwa akwa buru fashion designer ooo!...

Translation (NB: this translation should not strictly follow a line by line style but a summary form just good enough to provide the message required to avoid too much repeats)

My advice to everyone in this world is, let anybody that begets a child train him/her in school because education is important whether male or female, education is important in this world. Even if the child 
is poor and you have the resources train him/her, for whoever trains a poor child receives God's blessings

If a male child is educated, it is good. And if a female child is educated, it is equally good. Hence educated, the child can pick any trade, be it trading, be it white collar job, whatever the child likes he/she can do. So whether male or female child is child for no one knows the head that will wear the crown

If a woman is trained, she has so many opportunities. She can be a Medical Doctor, an Engineer, A Lawyer, or a Chief Judge. If she becomes a Minister and does well she can even be a President. In fact a trained woman seems to excel in all kinds of trade, if she takes up white collar job, she does it well, if she trades or cook, she does it even better, when it comes to sewing she measures with fashion designers.

This message-driven song has gone a long way in enlightening most parents who always feel despaired for mere fact that their wives have not been able to give birth to male children. Oliver gave them message of hope in their female children provided they are well trained. Far from sounding a feminist, these people should borrow a leaf from what is happening in societies and world over today, where women are seen occupying various prominent and sensitive positions in Government and other well known ventures too numerous to mention both within Nigeria and outside. Many are Politicians, Ministers, Commissioners, Senators, Heads of States, Members of House of Assembly and House of Representatives, name them. All these owe their credence to good education and proper upbringing.. Oliver De Coque 
acts as a crusader to enlighten parents to think in a right direction because when a woman is trained a nation is as well trained. Oliver has many other works to his credit such as -Ugbana k'etel'unyi naru, ugbana chakocha kochafodolu No matter how ostrich is painted black, it does not remove the fact that it is a white bird.

-Ibili o Ibili kam bili, onye azon'uwa azo, uwa ga-abata onye obuna

Live and let live, let no one struggle for this world because it will contain everybody.

-Uwa choro obi umeani, ejighi iwe eso enu uwa

The world requires harmonious co-existence and not strife etc All these point a way forward for the good of the nation.

\section{Fela Anikulapo kuti and his music}

Olufela Olusegun Oludotun Ransome-kuti was born in Abeokuta, Nigeria to a middle class family. He grew to become known as Fela Anikulapo Kuti, "The Black President" , the human rights activist, mid pioneering composer of Afrobeat, Fela released (about) 77 albums in his life time, spoke against the brutality of military and police force across Africa, and was targeted by the government of Nigeria for his political descent...(Oluwaseye, 201 I:200)

Most of Fela's songs capture societal appeal as they admonish, criticize, inform or create awareness in public affairs. They condemn drastically social evils in the society and among the ruling class. Fela acts as the mouthpiece of the commoners. $\mathrm{He}$ was both social and political crusader. According to Okafor (2005: 367), 'Fela Anikulapo Kuti, the Afro-beat exponent, was famous for his satires and his criticism of authority in music'. Some of his music includes -Zombie, 
Yellow fever, V.I.Ps (Vagabonds In Power), Lady, Gentleman, Fear Not for Man and so on.

Taking a stance from this popular song - V.I.Ps, Fela criticized those in authority as well as those that acquired Western Education and have nothing to show for it instead they use their positions to the detriment of the poor masses. They exploit and loot government coffers and create artificial scarcity and poverty. Fela uses pidgin English to convey most of his messages to the masses, thus

\section{V.I.P. (Vagabonds In Power)}

$\mathrm{Na}$ dem be head of State, commissioner, permanent secretary, judges, bank managers, and dem dem

You cannot be a big man copying colonial master

An African must be African

M.O.P. (Movement of the people)

Man get power, him take am cheat person

Man get power, him take am talk nonsense

Man get power, him take am steal money

Dem no know hungry people
Dem no know jobless people
Dem no know homeless people
Dem no know suffer people

Dem go dey ride best car

Dem go dey chop best food

Dem go live in best house

Dem go dey waka for road

You go dey comot for road for am

Dem go dey steal money

He be wrong man 
$\mathrm{Na}$ Vaganonds in Power

(Excerpt from Okafor , 2005)

Examining the above examples from these old musicians, one would agree that the songs carry a lot of messages which are in line with the aim of making music in Igbo culture as stated earlier in this discussion.

\section{New music and Musicians}

As was said earlier in this discussion, time is a demarcating factor between the two groups. The year 2000 and above represents new generation music and musicians. In this category, a lot of musicians have flooded entertainment industries with music short of societal expectations. They go on producing music that appeals to a particular group (the youths) in society whose sense of judgment between good and bad music is jeopardized. Most of the lyrics are filled with foul languages that the society abhors. Traditionally, use of words is most economical and sacrosanct when it concerns human anatomy and sexuality especially for a given age range. Regrettably, these groups of musicians derive more pleasure producing music that yield to moral degradation rather than improving it. A nation that is morally corrupt has lean chances of growth and development. Some of the new generation musicians include - Flavour, Wiz Kid, P. Square, Tuface Idibia, Timaya, Bracket and so on.

\section{Flavour and his music}

His real name is Chinedu Okoli. A native of Umunze in Orumba Local Government Area of Anambra State, Nigeria. He grew up in Enugu State from where his musical talent started manifesting. He began as a drummer in a local church in Enugu and through the help of their resident pastor; he was introduced to Chris I.Ordor who trained him on the 
basics of music. Flavor is widely known even beyond Africa. Some of his hits include- "Nwa baby" (Ashawo Remix), "Uplifted", "Adamma" and "Oyi Remix", "Shake shake" and so on. The texts of the last example goes thus

\section{Shake-shake}

Mr. Flavour on the microphone.

When you see a woman wey sabi shake am, you go know.

Are you ready now? Baby girl show them

Kpuchie, jaa-yee, kpuchie, jaa-yee (Close, open wide)

Akiri-kata nwata di mma aaa, baby you so fine, akiri-kata nwata di mma, baby you so fresh. Akiri-kata nwata di mma aaa, baby you so sweet. Akiri-kata nwata di mma aaa, baby you so fine. Ukwu salambara na-adi mma n'obi ooo!, shake ma'Oh! Shake ma' oh!... $(2 x)$

Shake, shake, shake Ukwu, shake e, shake ukwu, akiri-kata pampam, shake ukwu, akiri-kata pampam. shake ukwu...(2x)

Ukwu gi oh! Ukwu gi oh! Baby m-ooo! Baby, shake ooo... (Your waist ooo! Baby, shake your waist ooo!)

Jaa-yee, kpuchi-e, jaa-yee...(Open and Close)

The summary of Flavour's message in this excerpt includes looking at a beautiful woman shaking her waist (precisely the buttocks), opening them and closing them. One then wonders whether a beautiful woman is basically and naturally identified by the way she opens and closes her private parts or by being modest. Such renditions are what the present generation of youths clamour for, and that goes on to expose the level of moral decadence in society. This is where culture transfers have a damaging effect on some cultures- the lgbo in particular where vulgarism is frowned at, let alone coming from younger sects. Obviously inter-cultural hybridization does not apply in all situations. Although, going by ethical 
relativism theory, morality is relative to the norms of one's culture. That is, whether an action is right or wrong depends on the moral norms of the society in which it is practiced. Otherwise, there are no universal moral standards that can be universally applied to all people at all times. Nevertheless, each society has a code of conduct that guides its citizenry. In this case, the target population is unfortunately not well represented adjudging the fundamental moral stipulations of the Country Nigeria.

\section{Bracket and their Music}

Bracket represents a Nigeria Afropop and R\&B music duo in the persons of Obumneme Ali popularly called 'Smash' and Nwachukwu Ozioko also known as 'Vast'. Both of them grew up in Nsukka of Enugu State. While Vast has diploma and a degree in Mass Communication from the Institute of Management and Technology Enugu and University of Nigeria Nsukka respectively, Smash has a diploma in Social Works and a degree in Psychology from University of Nigeria Nsukka. The duo belongs to the later generation of musicians. According to Wikipedia account, the history of origin has several stories and allegations. They have many albums to their credit some of which include Yori-Yori, Happy Day, Ada Owerri, Muah muah and so on.

Taking a look from one of their songs- Muah muah, the texts follow thus

\section{Chorus}

Because the way you just dey dance dey make me do you muah muah

Because the way you just dey laugh dey make me do you muah muah

Again do you muah muah, do you muah muah 
Ahuh do you muah muah, do you muah muah

When I still dey for club, I see you fine girl

You come dey give me hug. Dey hug me well well

My friends dey talk to me, but I no see them

Because the way you just dey dance dey make me do you muah muah

Until you waka pass my side oo

$\mathrm{Na}$ girl I know say you dey my mind oo... etc

The above excerpt from cultural perspective and interpretation has no creditable message to the masses other than expression of illicit desires and sexuality represented by some untranslatable slangs 'muah- muah' interspersed with heavy sonic applications. There is no gain saying the fact that all these point towards excessive and undue demonstration of juvenile exuberance which has no positive contribution to nation building.

\section{Conclusion}

This paper has not claimed exhaustive discussion of music and musicians of the old and new generations, but considering these few examples one would automatically say that the old music and musicians portray the cultural expectations of people more than the new. It was clearly discovered that the majority of the music of the younger generation are hurriedly packaged without cultural considerations and censorship. This calls for concern as it does not paint any good image to the nation. In as much as the paper does not intend to condemn all of the new generation music as there are still some good ones, what the paper is propagating is the need for quality control. Judging from interviews with people, observations and background account the problem with these young musicians is partly as a result of lack of job opportunities in their area of 
specialization after their university education. Some are even school drop outs who have no other option of livelihood. If these people are well empowered, there won't be much increase in the number of non talented musicians who flood the music industry in a bid to make both ends meet. As a matter of fact, our music industries should try to brace themselves to the challenges and menaces of poor quality music and musicians if the Country should gain from such contributions and productions.

Eunice U. Ibekwe

Department of Music

Nnamdi Azikiwe University, Awka, Nigeria

\section{References}

Aliogo, J.E. (2012). Latest Music 20I I/20/2 Lyrics : Enugu. De Joe Publications

lbekwe, E.U. (20I0). Musicians and the philosophical dimension of African man. Awka Journal of Research in Music and the Arts. (AJRMA) 7,33-45. Department of Music ,Nnamdi Azikiwe University Awka

Ibekwe, E.U. (20I3). The role of music and musicians in promoting social stability in the Country. Ujah: UNIZIK Journal of Arts and Humanities. 14, 3, 159-173. Faculty of Arts, Nnamdi Azikiwe University Awka

Nzewi, M.and Nzewi, O. (2007). A contemporary study of musical arts informed by African Indigenous knowledge systems. 5,2\&3. Pretoria: Ciimda Series.

Oluwaseyi, K. (20II). Gender and sexuality in the music of Fela Anikulapo Kuti. Awka Journal of Research in Music 
and the Arts. 8, 200-219. Department of Music ,Nnamdi Azikiwe University Awka

Okafor, R.C. (2005) Music in Nigerian Society. Enugu: New Generation Books.

Okafor, R.C., Nwokike, F., Eziechi, C., Egudu, J. (1999). The Life and Works of Celestine Ukwu. Enugu: New Generation Books..

Okwu, L.C. (20I4). Life and works of Mike Ejeagha. A project submitted to the Department of Music, Nnamdi Azikiwe University Awka . In partial fulfillment of the requirements for the award of Diploma in Music. 